Exploring Departures Based on the Victim's Wrongful Conduct: U.S. v. Koon

Author(s): Tracey L. Meares

Source: Federal Sentencing Reporter, Vol. 7, No. 4, Criminal Law Defenses at Sentencing (Jan.

- Feb., 1995), pp. 201-204, 213

Published by: University of California Press

Stable URL: http://www.jstor.org/stable/20639790

Accessed: 14/10/2010 16:01

Your use of the JSTOR archive indicates your acceptance of JSTOR's Terms and Conditions of Use, available at http://www.jstor.org/page/info/about/policies/terms.jsp. JSTOR's Terms and Conditions of Use provides, in part, that unless you have obtained prior permission, you may not download an entire issue of a journal or multiple copies of articles, and you may use content in the JSTOR archive only for your personal, non-commercial use.

Please contact the publisher regarding any further use of this work. Publisher contact information may be obtained at http://www.jstor.org/action/showPublisher?publisherCode=ucal.

Each copy of any part of a JSTOR transmission must contain the same copyright notice that appears on the screen or printed page of such transmission.

JSTOR is a not-for-profit service that helps scholars, researchers, and students discover, use, and build upon a wide range of content in a trusted digital archive. We use information technology and tools to increase productivity and facilitate new forms of scholarship. For more information about JSTOR, please contact support@jstor.org. 


\section{EXPLORING DEPARTURES BASED ON THE VICTIM'S WRONGFUL CONDUCT: U.S. V. KOON}

\author{
Tracey L. Meares*
}

In United States $v$. Koon, 833 F. Supp. 769 (C.D. Cal. 1993), the district court sentenced Stacey Koon and Laurence Powell, two Los Angeles police officers, to 30 months imprisonment and two years supervised release for depriving the victim, Rodney King, of his constitutional rights under color of state law.

The 30-month sentences were substantially below the guideline range of 70 to 87 months. To reach the 30-month level the court relied on two theories of departure, one of which was the wrongful conduct of the victim. ${ }^{1}$ The factual context in Koon differed greatly from cases in which the departure provision previously had been applied. The Ninth Circuit found the departure unjustified and reversed. United States v. Koon, 34 F.3d 1416 (9th Cir. 1993).

Many would argue, and I agree, that the Ninth Circuit's repudiation of the sentencing court's departure in the Koon case is justified. However, the Circuit interprets too narrowly $\S 5 \mathrm{~K} 2.10$, which allows sentencing courts to depart from the guidelines when the victim's wrongful conduct contributes significantly to provoking the offense behavior. The Ninth Circuit's reading of $\S 5 \mathrm{~K} 2.10$ is not supported by the text, nor does it make sense as a policy matter. Moreover, the opinion offers little guidance on what constitutes the proper degree of departure under $\S 5 \mathrm{~K} 2.10$. The end result is that sentencing courts are given little discretion to use $\S 5 \mathrm{~K} 2.10$ to depart in other civil rights cases and possibly in cases outside that context.

\section{THE VICTIM CONDUCT POLICY STATEMENT (§5K2.10)}

That a defendant's punishment should be adjusted to account for the fact that his criminal conduct occurred in response to wrongful conduct by the victim is probably not a controversial claim. In fact, it might strike many people as an intuitive concept. This intuition is embodied in homicide doctrine, which traditionally has considered premeditated homicides to be more serious than those committed "in the heat of passion." The latter are designated "manslaughter" and penalized less severely than intentional homicides.

The federal sentencing guidelines have extended this intuition to apply to all violent offenses and some non-violent offenses. Section $5 \mathrm{~K} 2.10$ provides:

If the victim's wrongful conduct contributed significantly to provoking the offense behavior,

*Assistant Professor, University of Chicago Law School. the court may reduce the sentence below the guideline range to reflect the nature and circumstances of the offense. In deciding the extent of a sentence reduction, the court should consider:

(a) the size and strength of the victim, or other relevant physical characteristics, in comparison with those of the defendant;

(b) the persistence of the victim's conduct and any efforts by the defendant to prevent confrontation;

(c) the danger reasonably perceived by the defendant, including the victim's reputation for violence;

(d) the danger actually presented to the defendant by the victim; and

(e) any other relevant conduct by the victim that substantially contributed to the danger presented.

Sentencing courts have discussed their reliance on $\S 5 \mathrm{~K} 2.10$ in a few published cases. Many involve assault resulting in serious bodily injury on Indian reservations. Others include the mailing of threatening letters, extortion, and, interestingly, manslaughter. ${ }^{2}$

\section{THE SENTENCING COURT'S VIEW}

In the Koon case, Judge John G. Davies decided that $\$ 5 \mathrm{~K} 2.10$ was relevant in sentencing two police officers convicted of using unreasonable force to arrest Rodney Glen King. Judge Davies's sentencing memorandum states that King's wrongful conduct significantly contributed to provoking the unlawful conduct of the officers such that their "conduct fell outside the range of the more typical offenses for which the Guidelines were designed."

The sentencing court pointed to several examples of King's "illegal conduct" prior to and during his arrest: that he was intoxicated, that he exceeded the speed limit, and that he failed to stop his car even after the police flashed him. The court also observed that King was slow to obey orders, that he attempted to escape custody, that he is a big man and was a felony suspect at the time of the incident, relying on $\$ 5 \mathrm{~K} 2.10$ (a) and (c): "From the time of that first baton blow until 1:07:28 [referring to the frames of the famous Holliday tape] when the defendants' conduct crossed the line to illegality, Mr. King persisted in his failure to obey the police."

To the extent that the sentencing court relied on King's wrongful conduct as but-for causation of the entire incident, the court's interpretation of "significant provocation" in §5K2.10 seems rather weak. A portion of his opinion deserves greater attention, however: the relationship between volatility of the arrest situation and departures under $\S 5 \mathrm{~K} 2.10$.

The volatility analysis has two parts. One deals with but-for causation:

While Mr. King's wrongdoing precipitated the 


\section{VICTIM'S CONDUCT}

initial, lawful use of force, and thereby substantially contributed to the offense conduct,... [t]he Court recognizes that by the time the defendants' conduct crossed the line to unlawfulness, Mr. King was no longer resisting arrest. ... Nevertheless, the incident would not escalated to this point, indeed it would not have occurred at all, but for Mr. King's initial conduct.

That statement might be generalized as follows: In an excessive force case the victim's wrongful conduct can precipitate an incident in which a volatile arrest situation will ensue. In a volatile arrest situation we might expect the line between the lawful and unlawful conduct of a law enforcement officer to be very thin.

This part of the volatility argument suggests that there might be cases in which a victim's misconduct and resistance played a substantial part in provoking the police officer's conduct so that the sentence should be mitigated.

The second part of the volatility argument focuses on the officer's response to the victim's provocative conduct:

Police officers are always armed with 'dangerous weapons' and may legitimately employ those weapons to administer reasonable force. Where an officer's initial use of force is provoked and lawful, the line between legal arrest and an unlawful deprivation of civil rights within the aggravated assault guideline is relatively thin. [But] the criminal conduct of a state officer who launches an unprovoked assault on an individual in custody is dissimilar to the conduct of defendants Koon and Powell who, at least initially, were incited to use force... . [T] he sentence imposed must reflect this disparity.

This part of the argument reflects a more categorical approach in contrast to the first part of the volatility argument, which is more case-specific. The court argued that police officers are much more likely to be involved in dynamic arrest situations where some use of force is legitimate. Therefore, the argument goes, these officers should not be condemned in the same manner as state officials who are sentenced under $\$ 2 \mathrm{H} 4$.1, for engaging in unprovoked and deliberate assaults.

\section{THE CIRCUIT COURT'S REVERSAL}

The Ninth Circuit rejected the sentencing court's $\S 5 \mathrm{~K} 2.10$ departure analysis for three reasons. Its narrow interpretation of $\S 5 \mathrm{~K} 2.10$ seems inconsistent with the policy statement's text and with the application of the departure provision in prior cases. The Circuit failed to address the sentencing court's twopart volatility argument, which has merit in some cases even if not in this one.

\section{A. The Temporal Link to Victim Misconduct} First, the appellate court explained that the lower court's analysis was faulty because it did not link adequately King's wrongful conduct to the defendants' wrongful conduct. Capitalizing on the sentencing court's statement that King's wrongful conduct was the "initial provocation for the subsequent course of events," the Circuit implied that the sentencing court had to presume that King's wrongful conduct precipitated both the lawful and unlawful conduct of the officers. Then the appellate court argued that this concept of but-for causation was simply too broad to fit within $\S 5 \mathrm{~K} 2.10$ because a butfor causation analysis required no victim misconduct to justify a departure. The Circuit used as evidence that the sentencing court's theory was overbroad the fact that they found King's wrongful conduct to have subsided by the time the officers' unlawful conduct began.

At first blush, the Ninth Circuit's description of the sentencing court's but-for analysis of provocation as too-inclusive seems persuasive. However the Circuit cannot be right that a but-for causation definition of provocation would not require any victim misconduct to justify a departure because $\S 5 \mathrm{~K} 2.10$ does require misconduct. Therefore, the image that the Circuit attempted to invoke-that future police officer-defendants would be able to avail themselves of departures under $\S 5 \mathrm{~K} 2.10$ because the victim happened to be innocently walking down the street when a police officer decides to engage in an unprovoked attack-does not help a reader to understand the flaw with the sentencing court's opinion.

Another problem with the first prong of the Ninth Circuit's view is the court's reliance on the fact that King's misconduct had already subsided by the time the defendants' unlawful conduct began. The panel implied that the provocation concept embodied in $\S 5 \mathrm{~K} 2.10$ demands a short temporal link between the victim's provocative wrongful conduct and the defendants' subsequent offense. The rationale for a relatively short time lapse between victim's provocative wrongful conduct and the defendant's subsequent offense is straightforward. If the time lapse is very long, a defendant's conduct starts to look like planned revenge rather than a response the law considers justified because the act was committed "in the heat of passion."

The traditional concept of cooling-off time in manslaughter doctrine might offer support by analogy to a temporal requirement in $\S 5 \mathrm{~K} 2.10$. If too much time passes between the provoking event and the defendant's subsequent conduct, we might decide that the wrongful conduct of the victim no longer contributes significantly to provoking the offense behavior. However, even the cooling time rationale in manslaughter cases does not require that the defendant's conduct be simultaneous with the victim's provoking conduct, which is the standard implied by the Ninth Circuit in Koon. 


\section{VICTIM'S CONDUCT}

Moreover, and perhaps more importantly, the text of the policy statement does not require such a narrow temporal constraint. In fact, the text of the relevant subheadings of the policy statement militates in the opposite direction, for it specifically allows victim misconduct that occurred prior to the incident to be considered. $\$ 5 \mathrm{~K} 2.10(\mathrm{~b})$ refers to the persistence of the defendant's conduct, $\S 5 \mathrm{~K} 2.10$ (c) refers to danger reasonably perceived by the defendant, including the victim's reputation for violence, and the catch-all §5K2.10(e) mentions any other relevant conduct by the victim.

Finally, the Ninth Circuit's own illustrative example of a possible case for a $\S 5 \mathrm{~K} 2.10$ departure, a case in which a victim harms an officer's partner in the officer's presence, does not seem to require such a strict temporal link. The Circuit simply added an unnecessary requirement to $\S 5 \mathrm{~K} 2.10$ departure analysis by relying on a strict temporal requirement to bolster the strength of its attack on what it perceives as the over-inclusiveness of the sentencing court's but-for causation analysis.

\section{B. Volatility}

The Ninth Circuit's second argument against the $\S 5 \mathrm{~K} 2.10$ is framed around the following question: was it legally permissible for the sentencing court to find that a 5-level departure was justified because of the proximity between King's wrongful conduct, which had subsided by the time the officers' wrongful conduct commenced, and the "volatility" of the arrest situation?

The panel's answer, "No," was grounded in an analysis of the substantive law of excessive force claims set out in Graham v. Connor, 490 U.S. 386 (1989).

Graham directs juries to consider the volatility of the arrest situation in determining whether police officers are liable for civil rights violations flowing from unreasonable use of force in the arrest context. Thus, Graham teaches that the dynamic arrest situation that the sentencing court in Koon found to be unusual enough to consider for $\S 5 \mathrm{~K} 2.10$ departure analysis is not unusual at all. Rather, the volatility of the arrest situation is a factor inherent in excessive force cases. Therefore, said the Circuit, the volatility of the arrest situation cannot be unusual enough to justify a departure from the heartland of offenses contemplated by $\$ 2 \mathrm{H} 1.4$.

This part of the Ninth Circuit's opinion is much more persuasive than its first attack. But it too is flawed because of its rigidity.

The most direct way to address it is to ask: Are there cases in which the sentencing judge reasonably could conclude that the volatility of the situation could justify a departure even though the jury has already taken volatility into account at the liability stage? I think the answer should be yes. But the Ninth Circuit's reasoning removes categorically from the sentencing judge's consideration factors over which the jury deliberated at the liability stage in excessive force cases.

The Ninth Circuit's conclusion is at odds with the opinions of other courts addressing the applicability of Part K departures. For example, in United States $v$. Whitetail, 956 F.2d 857 (8th Cir. 1992), the court held it an error for the trial judge to treat the jury's rejection of a battered woman defense to murder as precluding a downward departure under $\$ 5 \mathrm{~K} 2.10$ on the same evidence. The Whitetail court relied on United States $v$. Cheape, 889 F.2d 477 (3rd Cir. 1989), which explained that sentencing departures on the basis of coercion or duress must be read more broadly than situations in which those factors are used to provide a complete defense. To read the provisions otherwise, the court stated, would render the policy statements meaningless.

It is unpersuasive to argue that because the volatility of the arrest situation is considered, along with many other factors, in the course of the jury's decision to impose liability, factors such as the volatility of the arrest and the victim's misconduct are not relevant at sentencing.

The volatility of the situation and the relationship between the volatility of the arrest and the particular victim's misconduct might be better addressed and refined at sentencing than at the liability stage. Considering this relationship at sentencing allows judges the discretion necessary to make contextualized decisions that recognize the differences between official misconduct that is deliberate and misconduct that occurs as reasonable force "morphs" into unreasonable force during an arrest.

Interpretations such as the Ninth Circuit's that link the departures to the success of a defense at the liability stage limit departures in a categorical manner that undermines even the very limited amount of discretionary sentencing afforded sentencing courts under the guidelines.

\section{Analogy to Deliberate Assaults}

Third, the Ninth Circuit attacked the sentencing court's attempt to distinguish law enforcement officers in excessive force cases from corrections officers who engage in deliberate and unprovoked assaults. Both groups of officials are subject to sentencing under $\S 2 \mathrm{H} 1.4$ which is titled Interference with Civil Rights Under Color of Law. This section makes no distinction between uses of force that initially are lawful and those that are not.

The sentencing court saw the law enforcement officer's use of excessive force in the volatile arrest situation as fundamentally different from and exculpating as compared to the case of a correction officer or other state agent (including a police officer) who intentionally uses a dangerous weapon to assault a victim without legitimate cause. The sentencing court was concerned that the stringent Aggravated 
Assault guideline $§ 2 \mathrm{~A} 2.2$, which applied to the Koon case through $\S 2 \mathrm{H} 1.4$, was applicable to a "heartland" of deliberate and unprovoked assaults. Because the Koon case involved an assault following from a volatile arrest situation, the court deemed a departure necessary.

The Ninth Circuit disagreed after evaluating the sentencing court's analysis: "The fact that appellants were authorized to use some force in this case does not mitigate the fact that they used too much. Under the structure and policies of the Guidelines, it makes it worse." The Circuit made a very good point. Unfortunately, it did not address the puzzle that the sentencing court attempted to solve.

Both the sentencing court and the circuit take rigid, categorical approachs that are inappropriate to the complex issues inherent to excessive force cases. The sentencing court suggested that all uses of force by police officers in the arrest context are similar to each other and dissimilar to unprovoked and deliberate uses of force by state officials outside the arrest context. The Circuit suggested that volatility never could be considered at sentencing because the jury considered that factor at the liability stage.

The Ninth Circuit relied on the forceful notion that $\S 2 \mathrm{H} 1.4$ correctly punishes more severely official misconduct than comparable conduct by private actors. The Circuit additionally pointed out that the fact that Koon and Powell were authorized to use some force in this case did not mitigate the fact that they used too much.

It is difficult to argue against these two statements. Moreover, it is understandable that the Circuit discussed the distinction between private and public actors in light of the fact that it characterized the sentencing court's discussion of its departure from the aggravated assault guidelines as an "implicit contrast between appellants [Koon and Powell] and civilian offenders."

But considering the distinction between public and private actors does not help solve the puzzle of how deliberate misconduct by officials and misconduct by officials occurring in situations where initial use of force is justified should be treated at sentencing. It is similarly unhelpful to point out that Koon's and Powell's limited authority to use some force in the volatile arrest situation does not justify use of excessive force. The puzzle we need to solve assumes the second point from the beginning. The Ninth Circuit does not address the implications of the sentencing court's forceful argument that we might view as more reprehensible the excessive use of force by government officials that has absolutely no explanation.

A better analysis would recognize that the appropriate comparison is between groups of officials engaging in misconduct under two different circumstances, rather than comparing private individuals and public individuals. Since civil rights violations flowing from uses of unreasonable force almost always involve some kind of misconduct by the victim in the course of a likely volatile arrest situation, perhaps the Sentencing Commission failed to take these factors into account in determining the heartland offenses for the aggravated assault guideline and the criminal civil rights guidelinecontrary to the sentencing court's conclusion.

Though it did not say so, it is more likely that the Commission believed that sentencing courts could accommodate some of the differences between these two groups of officials through variations in sentences along the guideline range. Since the Commisison did not say so and since 18 U.S.C. 3553(b) indicates that the Commission has a burden to make its decisions clear, courts probably should have more discretion to depart in these cases. And, to the extent that these differences cannot be accommodated, we could easily conclude that the case of unprovoked and deliberate assault by a state official demands an upward departure from the guideline sentence.

\section{A BETTER VIEW}

Even if variations along the guideline range can accommodate differences between the two groups of officials first discussed, the idea of significant provocation in the volatile arrest situation is still relevant to analyze a sentence. A serious analysis should address head-on the fact that provocation must include some assessment of the defendant's mental state in addition to the victim's wrongful conduct.

Several questions are relevant to whether a $\S 5 \mathrm{~K} 2.10$ departure is justified in an excessive force case. The sentencing judge should ask what the circumstances were, what kind of force was used, what the mental state of the defendant was, and what was the victim's wrongful conduct.

Even if the heartland offenses contemplated by the assault guideline as applied to police officers in civil rights cases take into consideration that arrests generally are volatile and occur in response to at least some misconduct on the victim's part, that heartland cannot describe every case. There is a difference between the arrestee who merely struggles and the arrestee who assaults the arresting officer. Both cases involve volatile arrest situations. Both could involve exercises of unreasonable force on the officer's part. The second case might justify a departure under $\S 5 \mathrm{~K} 2.10$.

Koon might be difficult case to consider a $\S 5 \mathrm{~K} 2.10$ departure for reasons that go beyond the inherent difficulties of using this departure provision in excessive force cases, which almost always involve some kind of victim misconduct and in which the defendant is rightly held to a higher standard than a

continued on page 213 
within $\S 242$ : the statute criminalizes the deprivation of all Constitutional rights. United States v. Price, 383 U.S. 787, 803, 16 L. Ed. 2d 267, 86 S. Ct. 1152 (1966) (discussing legislative history). Hence "once a due process right has been made specific by court decisions, that right is encompassed by $\S$ 242." United States v. Langer, 958 F.2d 522, 524 (2d Cir. 1992) (internal quotation marks and citations omitted). The rights King was deprived of have been clearly established for decades, and willful conduct which deprived him of those rights falls within the heartland of both the statute and the Guidelines. The fact that willful violators of the rights at issue in this case may not be prosecuted as often as other violators of $\S 242$ does not alter the analysis. In itself it says nothing about individual culpability, although it may say something about evidentiary difficulties and about the litigation strategies of the federal government.
${ }^{38}$ We do not conclude that a departure for victim misconduct would never be permissible in a police case. Such a departure might be appropriate, where, for example, the victim kills or wounds an officer's partner in his presence. In such a case, victim misconduct plays a role similar to that played by provocation in the more usual crimes of passion: the defendant is to a certain extent excused because he was seized by passion, and acted in the heat of the moment. This appears to have been the rationale in those cases where departures under $\S 5 \mathrm{~K} 2.10$ were affirmed. See United States $v$. Tsosie, 14 F.3d 1438 (10th Cir. 1994); United States v. Yellow Earrings, 891 F.2d 650 (8th Cir. 1989) (assaults triggered by sexual jealousy or humiliation). This is distinguishable from the district court's rationale, which relies on the vicissitudes of police work, and the difficulty in drawing the line between proper and improper uses of force.
Meares-continued from page 204

civilian. These reasons include the national attention focused on the case due to the potentially explosive race, ethnic, and class issues. The exceptional nature of the case and the explosive history could explain the Ninth Circuit's overly rigid response to Judge Davies's departures, for discretion can be dangerous in these cases in a way that many people rightfully consider to be illegitimate.

But it goes without saying that discretion can be a good as well. Allowing the sentencing court even limited discretion permits it to make more contextualized, more precise, and better decisions.

\section{FOOTNOTES}

${ }^{1}$ The other basis of departure was the convergence of three factors-additional punishment in the form of prison abuse and exposure to multiple adversarial proceedings; the absence of need to protect the public from these defendants; and the "unusual circumstance" of the defendants' indictment after the state court verdict.

${ }^{2}$ Allowing a departure from a guidelines sentence for manslaughter seems like double-counting since the substantive law of homicide takes provocation into account by downgrading the defendant's offense. Nevertheless in United States $v$. Tsosie, 14 F.3d 1438 (10th Cir. 1994), the sentencing court departed from the sentence range of 41-51 months to one of 4-10 months on a charge of manslaughter occurring in Indian country to which defendant pleaded guilty. Tsosie was sentenced to four months in a half-way house. 